\title{
Snakes: Ecology and Conservation
}

Edited by Stephen J. Mullin and Richard A. Seigel. 2009. Comstock Publishing Associates, Cornell University Press, Ithaca, New York. xiv +365 pages. 60.00 USD.

Rumours abound that snake researchers suffer from "lizard envy" because of the successful promotion of lizards as the new model research vertebrate in recent decades. To counter this impression, here is the fourth data-rich synthesis of snake research co-edited by Richard A. Seigel in the past 23 years. It joins three impressive predecessors: Snakes: Evolutionary Biology (1987, co-edited with J. T. Collins and S. S. Novak), Snakes: Ecology and Behavior (1993, coedited with J. T. Collins), and The Garter Snakes: Evolution and Ecology (1996, co-edited with D. E. Rossman and N. B. Ford). Why, then, yet another volume so soon after these benchmarks? The answer is simple, as, like other "reptiles" (in the traditional sense) and amphibians, the latter part of the $20^{\text {th }}$ and early $21^{\text {st }}$ centuries has seen an expanding explosion of detailed research on these groups, quickly making earlier volumes outdated. No longer are snakes largely ignored in response to the oft-quoted 1758 Christian biblical inspired dismissal by Linnaeus of all reptiles as merely "foul and loathsome". After years of inadequate study, increasing awareness and concern about the newest age of massive extinction brought on by ever-expanding human populations has brought attention even to snakes as indicators of our accelerated loss of biological diversity. This new volume is timely with its focus on conservation and habitat management to promote snake survival.

The book brings together the synthesis of current research by 24 contributors in 11 chapters preceded by an introduction by editors Mullin and Seigel "Opening the doors for snake conservation" and concluded with a chapter "Snake conservation, present and future". Between are chapters emphasizing the literature on innovative methods for studies of snake ecology and conservation. These include: molecular phylogegraphy; modeling snake distribution and habitat; linking behavioral ecology to conservation objectives; reproductive biology, population viability and options for field management; conservation strategies: captive rearing. Translocation, and repatriation; snakes as indicators and monitors of ecosystem properties; combating ophiophobia: origins, treatment, education, and conservation tools.

In addition, there are three chapters which include studies particularly relevant to Canadian naturalists and researchers. Patrick J. Weatherhead has joined with Thomas Madsen of Australia to author a chapter linking behavioural ecology to conservation objectives. Weatherhead was a pioneer in Canadian snake ecology. An ornithologist at Carleton University in Ottawa, conducted long-term field studies at the Queen's Biological Station north of Kingston and, early in these, became interested in the impact on bird populations by rat snakes (formerly Elaphe obsoleta, now best designated Pantherophis spiloides $\times$ alle- ghaniensis) [see H. L. Gibbs, S. J. Corey, G. BlouinDemers, K. A. Prior. and P. J. Weatherhead. 2006. Hybridization between mtDNA-defined phylogeographic lineages of Black Ratsnakes (Pantherophis sp.). Molecular Ecology 15: 3755-3767] and supervised theses by a number of graduate students on this species and on Neroidia and Thamnophis at the Queen's Biological Station and the Eastern Massasauga, Sisturus catenatus, at Bruce Peninsula National Park. He subsequently moved to the University of Illinois. This work has lead to a solid case for the separate designation of the two Ontario rat snake populations by COSEWIC (Committee on the Status of Endangered Wildlife in Canada) as endangered (Carolinian population in southern Ontario [Pantherophis spiloides] and threatened (the Great Lakes/St. Lawrence population, which includes the snakes on the Queen's University Field Station). Kent A. Prior, a former graduate student of Weatherhead's, now a critical habitat specialist with Parks Canada, has written, with New York based Americans, Kevin T. Shoemaker and Glenn Johnson, on habitat manipulation as a viable conservation strategy. Richard A. King of Northern Illinois University, has spent a career in comparative studies of the herpetofaunas of the islands shared between Ontario and Ohio at the western end of Lake Erie including Pelee and Middle islands in Canada. Although King's own research has had particular emphasis on the islands' endemic water snake subspecies, Nerodia sipedon insularum, his chapter on population and conservation genetics includes discussion of a broad number species, habitats, and varying selection pressures from a many studies elsewhere.

A disappointment with the book is its lack of authored contributions some other leading Canadian snake researchers. These include Gabriel Bloundin-Demars, a former graduate student of Weatherhead's now at Ottawa University who has carried on the rat snake and other research at the Queen's University Biological Field Station, and Patrick Gregory and his students at University of Victoria who have studied western snakes for more than three decades, although numerous papers of both groups are cited.

Make no mistake, clearly this book is pitched at the reference level for students and established researchers. But this does not mean that the interested naturalist would not gain much from its perspective of the current and future problems in assuring some snakes survive. Its comprehensive literature that pools the citations for all chapters is an impressive section in itself at 65 pages. Also useful are the two concluding indexes, a 5-page one to scientific and common names and a 4-page subject index

FRANCIS R. COOK

Researcher Emeritus, Canadian Museum of Nature, Ottawa, Ontario K1P 6P4 Canada 